\title{
WANITA RAWAN SOSIAL EKONOMI DI KECAMATAN SEMIN, GUNUNGKIDUL
}

\author{
Mohammad Nur Hidayat $^{1}$, Rifki Khoirudin ${ }^{2}$ \\ ${ }^{1,2}$ Progam Studi Ekonomi Pembangunan, Fakultas Ekonomi dan Bisnis, \\ Universitas Ahmad Dahlan
}

Email : rifki.khoirudin@ep.uad.ac.id

\begin{tabular}{ll}
\hline & \multicolumn{1}{c}{ ABSTRAK } \\
\hline Kata Kunci: & \multicolumn{1}{c}{ Sosial ekonomi merupakan suatu kondisi yang dapat } \\
WRSE, Status Pernikahan, & mempengaruhi seseorang dalam menjalankan kehidupan sehingga \\
Usia, Lama Pendidikan & buruk. Berdampak baik jika kesejahteraanna tinggi namun akan \\
Informal & berdampak buruk jika kesejahteraanya rendah dan mengakibatkan \\
& kesenjangan sosial, salah satunya adalah wanita rawan sosial ekonomi \\
& yang memilik kesejahteraan rendah, Wanita Rawan Sosial Ekonomi \\
& (selanjutnya disebut WRSE) merupakan permasalahan yang perlu \\
& diperhatikan, sebab salah satu faktor penyumbang kemiskinan adalah \\
& wanita rawan sosial ekonomi dimana pendapatannya dibawah rata-rata. \\
& Sehingga dengan pendapatan yang rendah mengakibatkan kesenjangan \\
& sosial. Kecamatan Semin merupakan kecamtan yang memiliki kasus \\
& PMKS khususnya pada WRSE yang tertinggi di Kabupaten \\
& Gunungkidul. Penelitian ini bertujuan untuk menganalisis variabel \\
& independen meliputi, status pernikahan, usia, dan lama pendidikan \\
& informal apakah berpengaruh signifikan terhadap wanita rawan sosial \\
& ekonomi. Bentuk data yang digunakan adalah cross section. Pengujian \\
& hipotesis dilakukan regresi logistik dengan analsis logit yang diolah \\
menggunakan aplikasi SPSS. Penentuan jumlah sampel dalam & penelitian ini ditentukan secara acak, kemudian jumlah sampel dihitung \\
menggunakan rumus Slovin yaitu sebesar 93 responden. Hasil \\
penelitian menunjukan dari tiga variabel independen hanya satu \\
variabel yang tidak mempengaruhi WRSE yaitu usia, sedangkan \\
variabel status pernikahan dan lama pendidikan informal signifikan \\
berpengaruh terhadap wanita rawan sosial ekonomi di Kecamatan \\
Semin, Gunungkidul.
\end{tabular}




\section{PENDAHULUAN}

Wanita Rawan Sosial Ekonomi (WRSE) merupakan wanita dewasa yang berusia lebih dari 15 tahun keatas baik, belum menikah, sudah menikah atau janda, yang berpenghasilan namun tidak cukup untuk memenuhi kebutuhan hidupnya, dan wanita tersebut merupakan kepala rumah tangga, kondisi tersebut tentunya tidak terlepas dari pendidikan yang pernah di tempuh, karena pendidikan sangat mempengaruhi pola pikir setiap individu. Tuntutan ekonomi yang berat mendorong perempuan untuk mencari nafkah demi kesejahteraanya, berbagai motivasi perempuan bekerja, yaitu suami tidak memiliki penghasilan yang cukup sehingga mengakibatkan rendahnya pendapatan rumah tangga, sedangkan tanggungan cukup berat pada keluarganya, sehingga perempuan akan bekerja untuk mencari uang sendiri untuk menafkahi seluruh anggota keluarganya.

\section{Menurut Kementrian Sosial}

Republik Indonesia, wanita rawan sosial ekonomi memiliki kriteria diantaranya pencari nafkah bagi keluarganya, pendidikan rata-rata rendah, berpenghasilan sangat kurang, jika dihitung dari segi penghasilan, di dapat dengan cara mengetahui angka garis kemiskinan di bagi 30 hari, jika garis kemiskinan pada Bulan September 2018 BPS mencatat sebesar Rp.425.250 per kapita per bulan, dapat dihitung bahwa dengan garis kemiskinan dibagi 30 hari, maka didapat angka sebesar Rp.14.175 ribu perhari, jadi agar dapat terbebas dari penyandang WRSE maka harus memiliki pendapatan diatas angaka Rp.14.175. Dalam kasus kemiskinan terdapat berbagai faktor yang mendorong terjadinya kemiskinan, dalam penelitian ini salah satu faktor penyumbang terjadinya kemiskinan adalah WRSE, dimana kondisi tersebut adalah wanita dengan kondisi yang kurang layak, dari segi yang dapat dilihat yaitu penghasilan, yang digunakan untuk memenuhi kebutuhan hidup, yang akan berdampak pada kondisi sosial ekonomi wanita tersebut, sehingga ketika angka WRSE terus miningkat maka secara otomatis tingkat kemiskinan juga ikut meningkat.

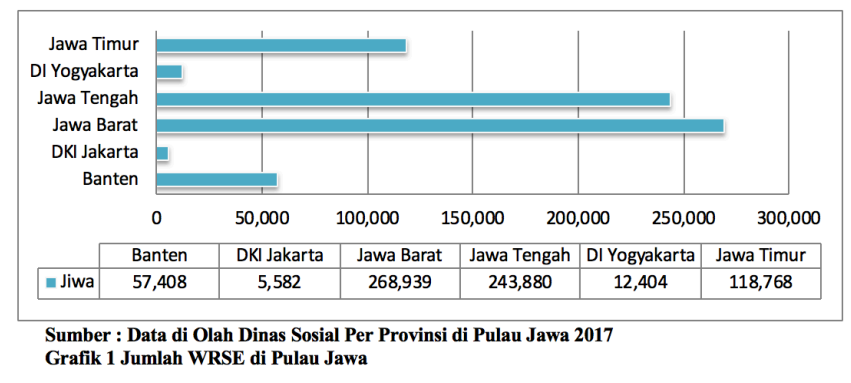

Dapat diketahui pada tabel grafik di atas, bahwasanya Provinsi DIY merupakan profinsi terendah ke dua di antar 6 provinsi di Pulau Jawa, dimana Jawa barat dengan posisi pertama yang memiki penyandang WRSE terbandak dengan angka 268.939 jiwa, dan di ikuti Jawa Tengah dengan angka 243.880 jiwa, Jawa Timur dengan angka 118.768 jiwa, Banten sebanyak 57.408 jiwa dan DKI Jakarta merupakan Provinsi yang memiliki penyandang WRSE terendah sebesar 5.582 Jiwa, namun banyak pertimbangan yang dapat diambil, diantaranya adalah DIY merupakan provinsi yang memeiliki empat kabupaten dan satu kota yang ada di pualu jawa, walaupun terendah ke dua angka 12.404 jiwa cukup tinggi bagi provinsi yang hanya memiliki empat kabupaten dan satu kota dibandingkan dengan lima dari enam provinsi yang ada di Pulau Jawa, dengan berbagi faktor yang dapat menyebabkan adanya WRSE sehingga akan mengakibatkan semakin meningkatnya angka kemisikinan.

Wanita rawan sosial ekonomi di Provinsi DIY tahun 2014 menjadi tahun yang terbanyak penyandang WRSE sebanyak 
13.116, bahkan di setiap tahunya mengalami kenaikan dan penurunan yang signifikan, dan dalam penelitian ini berdasarkan data tahun 2019, dalam kajian statistik bahwa BPS mencatat kepala rumah tangga perempuan di Gunungkidul sebanyak 69,10\%, Kabupaten Gunungkidul merupakan Kabupaten yang terdapat kasus WRSE tertinggi dibandingkan dengan kabupaten lainya, yaitu sebesar 3978 jiwa, dan Kabupaten Bantul sebanyak 3068 jiwa, Kabupaten Sleman dengan angka 2435 jiwa, Kabupaten Kulonprogo sebanyak 2089 jiwa dan terakhir Kota Yogyakarta dengan jumlah sebesar 883 jiwa dan di Kecamatan Semin Kabupaten Gunugkidul yang memiliki kasus penyandang WRSE sebesar 1360 jiwa. (Supriyadi dan Atmoko, 2018) dalam kajian statistik kesejahteraan Gunungkidul kepala rumah tangga perempuan dengan usia 15 tahun keatas serbanyak $76 \%$. Dalam kasus kemiskinan terdapat berbagai faktor yang mendorong terjadinya kemiskinan, dalam penelitian ini salah satu faktor penyumbang terjadinya kemiskinan adalah WRSE, dimana kondisi tersebut adalah wanita dengan kondisi yang kurang layak, dari segi yang dapat dilihat yaitu penghasilan, yang digunakan untuk memenuhi kebutuhan hidup, yang akan berdampak pada kondisi sosial ekonomi wanita tersebut, sehingga ketika angka WRSE terus miningkat maka secara otomatis tingkat kemiskinan juga ikut meningkat.

Secara umum pengertian tentang sosial ekonomi belum ada pengertian yang detail, karena sosial merupakan cabang ilmu yang mempelajari interkasi antar individu maupun kelompok, sementara ekonomi merupakan cabang ilmu yang mempelajar asas kemakmuran, jadi dalam pengertian sosial ekonomi masih terbagi dari dua cabang ilmu yang berbeda, namun jika kita sadari bahawasanya dapat diambil dari dua hal yang berbeda ini, namun sangat berkaitan erat, salah satu bentuk keeratan dua hal tersebut adalah ketika keperluan atau kebutuhan ekonomi suatu individu, belum atau bahkan tidak tercukupi maka akan menimbulakan dampak kesenjangan sosial anatar individu. Kesenjangan sosial dan ketimpangan pendapatan adalah masalah sosial ekonomi yang harus di selesaikan dan menjadi perhatian bersama bukan hanya pemerintah saja. Yang dapat di lakukan pemerintah yaitu memberikan progam pemberdayaan untuk mensejahterakan atas warganya untuk mendapatkan kondisi yang lebih layak, baik dari segi pendapatan, tempat tinggal, kesehatan, pendidikan dan lainya. Dalam sebuah keluarga, perempuan sejatinya bukan hanya menjadi seorang istri, namun perempuan juga berperan sangat penting dalam menjalankan sebuah keluarga, ketika kebutuhan keluarga tersebut tidak terpenuhi, maka peran perempuan akan bertambah untuk memenuhi kebutuhan dalam keluarganya, dengan cara mencari nafkah tambahan demi kelangsungan hidup seluruh annggota keluarganya.

Menurut badan pusat statistik status pernikahan hanya memiliki empat jenis, diantaranta adalah belum menikah, menikah, cerai hidup dan cerai mati. Menikah merupakan status yang terjalin dari dua insan yang menjadi status pernikahan. Status pernikahan scara hukum sah apabila sesuai dengan adat, agama dan negara atau lainya sesuai prosedur lainya, dan hidup bersama serta masyarakat menganggap sepasang suami. Menurut undang-undang pernikahan, pernikahan adalah ikatan lahir batin antara seorang pria dan wanita sebagai suami istri dengan tujuan membentuk keluarga, pada asas suatu perkawinan seorang pria hanya boleh mempunyai seorang isteri, dan seorang wanita hanya boleh mempunyai seorang suami. Hak kedudukan istri adalah seimbang dengan hak dan 
kedudukan suami dalam kehidupan rumah tangga yang menjadi sendi dasar dari susunan masyarakat, adapun putusnya suatu hubungan perkawinan, dapat putus karena, kematian, perceraian dan atas keputusan pengadilan. Perceraian hanya dapat dilakukan didepan sidang pengadilan yang bersangkutan berusaha dan tidak berhasil mendamaikan kedua belah pihak, dalam kasus suatu perceraian harus ada alasan yang cukup. Akibat dari putusnya suatu ikatan pernikahan karena perceraian, baik ibu atau bapak tetap berkewajiban untuk memelihara dan mendidik anak-anaknya, semata-mata berdasarkan kepentingan anak, bila mana terdapat perselisihan maka pengadilan bisa memutuskan untuk memberikan kewajiban kepada salah satu diantara kedua orangtuanaya. Menurut (Supriyadi, dan Atmoko 2018) dalam Statistik Kesejahteraan Rakyat Kabupaten Gunung Kidul, berpendapat bahwa dari semua kepala rumah tangga perempuan yang usia diatas 15 tahun keatas sebanyak $76 \%$, dengan terjadinya perceraian maka yang menjadi kepala rumah tangga perempuan, sehingga mengakibatkan kurangnya kesejahteraan yang dimilik seorang kepala rumah tangga perempuan. Status pernikahan merupakan indikator yang dapat digunakan untuk mengetahui seorang wanita dapat digolongkan pada masalah wanita rawan sosial ekonomi, yang menjadi tolak ukur, dengan kriteria ketika seorang wanita memiliki status pernikahan dengan status belum menikah, menikah ataupun janda serta menjadi kepala rumah tangga tidak ada yang menjamin kesejahteraanya sehingga harus mencukupi kesejahteraanya sendiri, status pernikahan berpengaruh, adapun kontek berpengaruh diantaranya yaitu berpengaruh positif dan berpengaruh negatif, berpengaruh positif jika seorang wanita dengan status status pernikahan belum menikah, menikah dan cerai tidak memiliki kesejahteraan yang cukup, sedangkan berpengaruh negatif ketika seorang wanita memiliki status pernikahan baik belum menikah, menikah atau cerai memiliki kesejahteraan yang cukup, sehingga status pernikahan memiliki hubungan berpengaruh terhadap tingkat kesejahteranya.

Menurut BPS usia merupakan satuan hitung untuk mengetahui dari usai seseorang, median usia penduduk Indonesia tahun 2010 adalah 27,2 tahun, angka ini menunjukan bahwa penduduk Indonesia termasuk kategori menengah, penduduk suatu wilayah dikategorikan penduduk muda bila median umur $<20$, penduduk mengah jika median umur 20 30 , dan penduduk tua jika median usia $>30$ tahun. Rasio ketergantungan penduduk Indonesia adalah 51,31. Angka ini menunjukan bahwa setiap 100 orang usia produktif (15-54) terdapatt sekitar 51 orang usia tidak produktif (0-14 dan 65+), yang menunjukan banyaknya beban tanggungan penduduk suatu wilayah. Rasio ketergantungan di daerah perkotaan adalah 46,59 sementara di daerah perdesaan 56,30. Perkiraan umur rata-rata umur kawin pertama penduduk laki-laki sebesar 25,7 tahun dan perempuan 22.3. Penduduk dengan usia produktif adalah penduduk dengan usia diantara 15 hingga 64 tahun, sedangkan usia tidak produktif merupakan penduduk dengan usia diatas 64 tahun. Dalam penelitian ini usia seseorang bisa mempengaruhi berbagai aktifitas sehingga dapat memenuhi kesejahteraanya, status pernikahan memiliki hubungan berpengaruh, dalam artian dapat berpengaruh positif dan berpengaruh negatif terhadap wanita rawan sosial ekonomi, berpengaruh positif ketika usia seseorang bertambah semakin tua maka akan terkendala dengan fisiknya, sedangkan berpengaruh negatif ketika usia seseorang yang masih muda, sehingga dapat menjalankan aktifitas yang dapat 
dikerjakan dan dapat mencukupi kesejahteraanya. Menurut (Dewi, 2012) semakin dewasa seseorang maka keterampilan pada bidang tertentu akan semakin meningkat, namun disisilain pada usia yang sudah tidak lagi produktif, keterampilan dan fisik sesorang akan mengalami penurunan. Perbedaan kekuatan fisik usia dewasa dan muda akan sangat berbeda. maka usia memiliki hubungan berpengaruh terhadap wanita rawan sosila ekonomi.

Pendidikan informal merupakan pendidikan yang di tempuh diluar jalur formal secara berjenjang dan berstuktur. Seperti pendidikan khusus untuk melatih potensi yang ada pada diri seseorang, pendidikan banyak jenisnya seperti prasekolah atau PAUD, tempat pemberdayaan, pendidikan keterampilan, dan penyetaraan pendidikan seperti kejar paket A, B, C, dan pendidikan lainya, yang khususkan untuk mengembangkan kemampuan diri. Dengan lamanya menempuh pendidikan diharapkan bahwa seseorang akan mendapatkan pekerjaan yang layak, dan lama-kelamaan dapat menciptakan lapangan kerja baru dan mendapatkan pengalaman yang lebih baik. Pendidikan informal menurut dinas pendidikan dan kebudayan, dengan adanya pendidikan informal diharapkan mampu untuk mendapatkan pekerjaan yang layak atau keahlian yang terdapat pada diri seseorang, menurut (Rizal dan Chandra 2016) pendidikan digolongkan menjadi dua, pendidikan formal dan pendidikan informal, pendidikan informal merupakan tempat untuk seseorang mendapatkan pengetahuan umum untuk mengembangkan bakat yang ada pada dirinya, jadi ketika seseorang memiliki pendidikan yang tinggi atau suatu keahlian sehingga dapat memenuhi kesejahteraanya, dimana WRSE adalah seorang wanita yang keadaan kesejahteraanya rendah, sehingga pendidikan informal berpengaruh negatif terhadap wanita rawam sosial ekonomi.

Penelitian yang dilakukan oleh (Juwono, dkk, 2012) Wanita Rawan Sosial Ekonomi adalah wanita dewasa belum menikah atau sudah menikah atau sudah janda tidak mempunyai penghasilan yang cukup untuk dapat memenuhi kebutuhan pokoknya sehari-hari dalam penelitianya kelompok wanita masih mendominasi sebagai kelompok yang rentan terhadap penyandang WRSE. Dalam penelitian yang

dilakukan oleh (Dewi, 2012) motivasi perempuan untuk bekerja diantaranya adalah suami tidak bekerja, pendapatan rumah tangga rendah dan jumlah tanggungan rumah tangga yang tinggi. (Astuti, 2012) dalam penelitianya tentang pemberdayaan perempuan miskin berbasis pemanfaatan sumberdaya lokal, jumlah keluarga miskin masih cukup tinggi sehingga pemeberdayaan wanita miskin dengan pemanfaatan basis sumberdaya lokal dapat mengentaskan kemiskinan. (Budhi, 2013) dalam penelitianya tentang analisis fakor-faktor yang berpengaruh terhadap pengentasan kemiskinan di Bali, kemiskinan merupakan penyakit bagi negara berkembang diantaranya seperti jumlah penduduk miskin, pertanian, industri dan PDRB berpengaruh terhadap pengentasan kemiskinan di Bali. (Rizal dan Chandra, 2016) dalam penelitianya faktor-faktor yang mempengaruhi wanita berwirausaha kondisi sosial ekonomi yang sedang lemah dan sulitnya mencari pekerjaan, sangat berpluang bagi wanita untuk mengasah kemampuan yang ada di suatu kelompok atau individu dari wanita tersebut.

Dari kajian diatas sehingga penelitian ini perlu untuk mengetahui apakah status pernikahan, usia dan lama pendidikan informal mempengaruhi WRSE, adapun tujuan penelitian ini untuk mengetahui apakah status pernikahan, usia dan lama 
pendidikan informal berpengaruh terhadap WRSE, dengan dugaan bahwa status pernikahan dan usia berpengaruh terhadap WRSE serta lama pendidikan informal berperngaruh negatif terhadapWRSE.

\section{METODOLOGI}

Penelitian ini merupakan penelitian dengan pendekatan deskriptif dengan jenis penelitian kuantitatif. Menurut (Sugiyono, 2012) metode kuantitatif merupakan metode yang digunakan untuk meneliti pada populasi atau sampel tertentu, pengumpulan data menggunakan instrumen penelitian, dengan analisis data yang bersifat kuantitatif atau statistik, dengan tujuan untuk menguji hipotesis yang telah di tetapkan. Adapun data yang digunakan dalam penelitian ini adalah data cross section, dimana data variabel independen diantaranya status pernikahan, usia, dan lama pendidikan informal yang diambil bersama-sama, akan di uji dengan alat analisis SPSS, dengan metode analisis regresi logistik dengan analsis logit, karena dalam penelitian ini veriabel terikat menggunakan model probabilitas, dalam penelitian ini lokasi penelitian di Kecamatan Semin, Kabupaten Gunungkidul, populasi sebanyak 1360 jiwa yang menyandang masalah kesejahteraan, khususnya wanita rawan sosial ekonomi. Penentuan jumlah sampel dengan cara acak (simple random samping), jumlah sampel yang akan diteliti yaitu menggunakan rumus Slovin sehingga di dapat jumlah populasi sebanyak 93 responsen dengan nilai eror sebesar $10 \%$.

Merupakan teknik statistik yang tepat untuk ketika variabel dependen berbentuk kategorikal, dan variabel independen dapat berbentuk numerik atau non-metrik, pada logistic regresi tidak mensyaratkan banyak asumsi seperti normalitas data namun hasil data data tetap robust walaupun ada asumsi yang dilanggar, jika hanya ingin memprediksi dua kategorikal variabel dependen maka analisis ini disebut binary logistic variabel. Namun ketika akan memprediksi lebih dari dua kategori dalam variabel dependen maka kita harus menggunakan multi nominal logistic regresi. Adapun pemilihan metode ini adalah data yang digunakan dalama penelitian ini bersifat non-metrik pada variabel dependen, sedangkan variabel dependen merupakan campuran dari data metrik dan kategorikal, karena adanya campuran skala pada variabel bebas menyebabkan multivariate normal distribution tidak dapat terpenuhi dengan kata lain tidak harus berdistribusi normal. Analisis logit digunakan untuk menganalisis data kuantitatif yang mencerminkan dua pilihan atau biasa disebut binary logistic regression. Regresi logistik bertujuan untuk menguji apakah probabilitas terjadinya variabel terikat dapat diprediksi dengan variabel bebasnya. Analisis ini digunakan untuk mengetahui pengaruh variabel status pernikahan (X1), usia (X2), lama pendidikan informal (X3). Adapun bentuk persamaan regresi logit sebagai berikut :

$$
L n=\frac{P i}{1-P i}=W R S E=F(X 1, X 2, X 3)
$$

Berdasarkan model diatas, persamaan regresi sebagai berikut :

$$
\begin{aligned}
L n= & \frac{P i}{1-P i}=W R S E \\
& =\alpha+b 1 X 1+b 2 X 2 \\
& +b 3 X 3+e
\end{aligned}
$$

Keterangan :

WRSE : Wanita Rawan Sosial Ekonomi

X1 : Status pernikahan

$\mathrm{X} 2$ : Usia

X3 : Lama Pendidikan Informal

b : Koefisien regresi

e : Eror tern (variabel pengganggu) 
Uji kelayakan model (Goodness of fit) digunakan untuk menguji kelayakan suatu model, yaitu model telah sesuai atau tidak sesuai. Kelayakan model regresi dinilai dengan menggunakan Hosmer and Lemeshow's Goodness of fit test. Jika nilai statistik Hosmer and Lemeshow's Goodness of fit test $\leq$ 0,05 maka terdapat perbedaan signifikan antara model dengan nilai observasinya sehingga Goodness fit model tidak baik karena model tidak dapat menilai observasinya. Jika nilai Hosmer and Lemeshow's Goodness of fit test $>0,05$ maka model mampu memprediksi nilai observasinya atau model dapat ditermia karena cocok dengan data observasinya Nagelkerke $R$ square merupakan modifikasi dari koefisien $C o x \in \mathcal{E}$ Snell untuk memastikan bahwa nilainya bervariasi dari 0 sampai 1 . Hal ini dilakukan dengan cara membagi nilai Cox E Snell R2 dengan nilai maksimumnya. Nilai yang kecil berarti kemampuan variabel-variabel independen memberikan variasi variabel dependen.

Uji signifikansi model Pengujian signifikansi secara simultan (Overall Model Test) Uji statistika ini untuk mengetahui apakah semua variabel independen didalam regresi logistik secara serentak atau simultan mempengaruhi variabel dependen sebagaimana uji $F$ dalam regresi linier. Uji overall model fit didasarkan pada nilai statistika -2Log Likelihood atau nilai Likelihood Ratio. Pada OLS untuk menguji signifikansi simultan menggunakan uji F, sedangkan pada regresi logistik menggunakan nilai $\mathrm{Chi}$ Square dari selisih antara -2Log Likelihood sebelum variabel independen masuk model dan -2Log Likelihood setelah variabel independen masuk model. Pengujian dilakukan dengan membandingkan selisih nilai -2Log Likelihood (Chi Square hitung) dimana apabila nilai chi-square hitung lebih besar dari chi square tabel atau nilai signifikansi lebih kecil dari alpha maka dapat dikatakan bahwa terdapat pengaruh secara simultan variabel bebas terhadap variabel terikat.

Pengujian signifikansi secara parsial (Uji Wald) dalam regresi logistik uji Wald digunakan untuk menguji ada tidaknya pengaruh dari variabel bebas terhadap variabel terikat secara parsial dengan cara membandingkan nilai statistik Wald dengan nilai pembanding Chi square pada derajat bebas $(\mathrm{db})=1$ pada alpha $5 \%$ atau dengan membandingkan nilai signifikansi (p-value) dengan alpha sebesar 5\% dimana (p-value) yang lebih kecil dari alpha menunjukkan bahwa hipotesis diterima atau terdapat pengaruh yang signifikan dari variabel bebas terhadap variabel terikat. Uji Wald (Z) dalam regresi logistik setara dengan uji $t$ pada OLS yaitu digunakan untuk menguji pengaruh secara individu variabel independen terhadap variabel dependen.

Pengujian apriori dilakukan dengan cara membandingkan kesesuaian tanda variabel estimasi yang digunakan dengan teori ekonomi. Apabila telah sesuai maka dapat dikatakan model yang diestimasi telah lolos dalam uji ini. Tanda positif menunjukkan variabel independen searah dengan variabel dependen, sedangkan tanda negatif menunjukkan arah yang berlawanan.

\section{HASIL DAN PEMBAHASAN}

Tabel 1 Uji Kelayakan

Hosmer and Lemeshow Test

\begin{tabular}{|l|l|l|l|}
\hline Step & Chi-square & Df & Sig. \\
\hline 1 & 10.051 & 8 & .261 \\
\hline
\end{tabular}

Sumber : Olah Data

Hipotesis :

Ho

mampu menjelaskan data 
$\mathrm{Ha}$ mampu menjelaskan data

Jika signifikan $<0,05$ maka model tidak cukup mampu menjelaskan data, sedangkan signifikan > 0,05 maka model telah cukup mampu menjelaskan data. Dari tabel diatas bahwa nilai sig $=0,261$ yang berarti lebih dari 0,05 maka keputusannya adalah menerima $\mathrm{Ha}$ sehingga model telah cukup mampu menjelaskan data/sesuai dengan kata lain model dinyatakan layak atau fit untuk digunakan analisis selanjutnya.

Tabel 2 Pengujian Koefisien Determinan

\begin{tabular}{|l|l|l|l|}
\hline \multicolumn{3}{|l|}{ Model Summary } \\
\hline Step & $\begin{array}{l}-2 \\
\text { likelihood }\end{array}$ & R Square & R Square \\
\hline 1 & $64.608^{\mathrm{a}}$ & .439 & .610 \\
\hline
\end{tabular}

Sumber : Olah Data

Hasil output estimasi model summary, untuk melihat kemampuan variabel independen dalam menjelaskan variabel dependen, digunakan nilai Cox \& Snell $R$ square dan Nagelkerke $R$ square. Nilai-nilai tersebut disebut juga dengan pseudeo $R$ square atau jika pada regresi (OLS) lebih dikenal dengan istilah $R$ square. Nilai Nagelkerke $\mathrm{R}$ square sebesar 0,610 yang menunjukkan bahwa kemampuan variabel independen dalam menjelaskan variabel dependen adalah sebesar 0,610 atau $61 \%$ dan terdapat $100 \%-61 \%=39 \%$ faktor lain di luar model yang menjelaskan variabel dependen. Variabel status pernikahan, usia dan lama pendidikan infromal dapat menjelaskan WRSE sebesar $61 \%$ sisanya di jelaskan diluar model.
Tabel 3 Pengujian Ketetapan Model

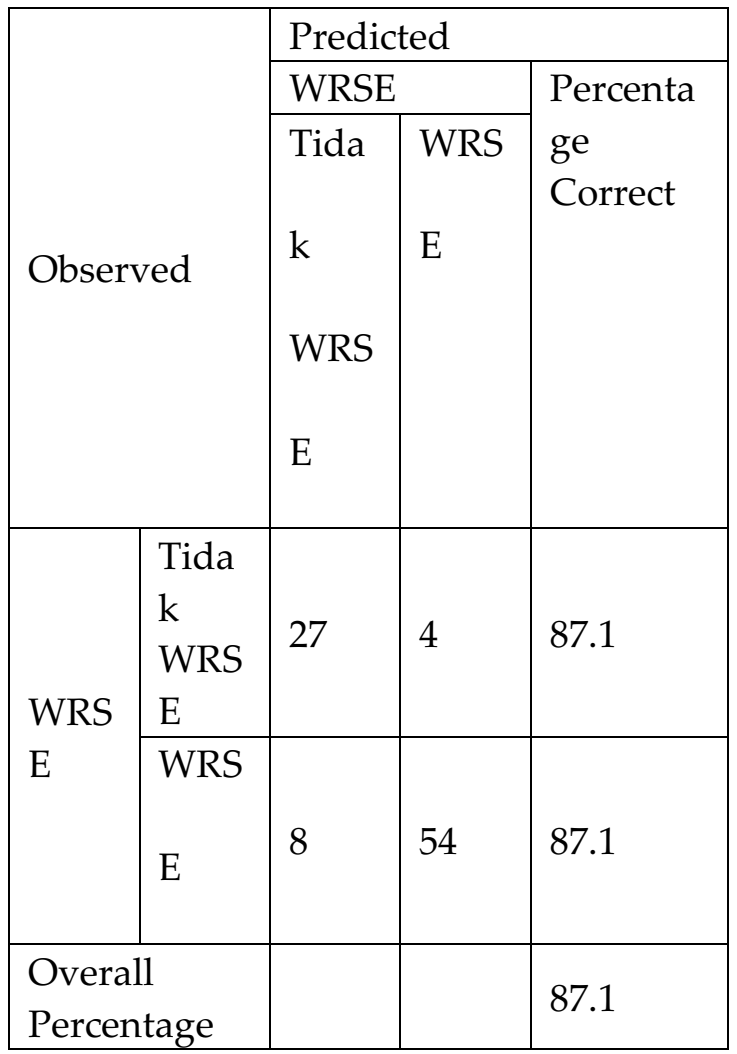

Sumber : Olah Data

Berdasarkan tabel pengujian presentase ketepatan model penelitian pada classification table jumlah sampel yang tidak menyandang WRSE sebanyak $27+4=31$ Orang, yang benarbenar tidak menyandang WRSE sebesar 27 dan seharusnya yang tidak menyandang WRSE namun terdampak sebanyak 4 orang, Jumlah sampel yang terdampak penyandang WRSE sebanyak $8+54=62$ orang dan yang benarbenar terdampak penyandang WRSE 54 orang, dan yang seharusnya terdampak namun tapi tidak terdampak sebanyak 8 orang. Dalam interpretasi regresi logistik dengan SPSS: tabel di atas memberikan nilai overall percentage sebesar $(27+54) / 93 \times 100 \%=87,1 \%$ yang berarti ketepatan model penelitian ini adalah sebesar $87,1 \%$. 
Tabel 4 Uji Apriori

\begin{tabular}{|l|l|l|l|l|}
\hline $\begin{array}{l}\text { N } \\
\text { o }\end{array}$ & Variabel & $\begin{array}{l}\text { Hipote } \\
\text { sis }\end{array}$ & $\begin{array}{l}\text { Has } \\
\text { il }\end{array}$ & $\begin{array}{l}\text { Keteran } \\
\text { gan }\end{array}$ \\
\hline 1 & $\begin{array}{l}\text { Status } \\
\text { pernika } \\
\text { han }\end{array}$ & \pm & + & Sesuai \\
\hline 2 & Usia & \pm & + & Sesuai \\
\hline 3 & $\begin{array}{l}\text { Lama } \\
\text { pendidi } \\
\text { kan } \\
\text { infromal }\end{array}$ & - & - & Sesuai \\
\hline
\end{tabular}

Pengujian apriori dilakukan dengan cara membandingkan antara hipotesis dengan hasil. Apabila pengujian sesuai antara hipotesis dengan hasil penelitian maka dapat dikatakan model yang diestimasi telah lolos uji apriori. Berdasarkan hasil tersebut dapat disimpulkan bahwa status pernikahan memiliki hipotesis berpengaruh dimana dalam kontek berpengaruh terdapat dua arah bisa mengarah positif dan mengarah negatif, sehingga pengujian variabel status pernikhan di uji dengan dua arah positif atau negatif dan dalam penelitian ini berarah ke postif sehingga pengujian ini telah sesuai antar hipotesisi dan hasil, sehingga variabel status pernikahan telah lolos uji apriori.

variabel usia di uji dengan dua arah, dan tidak berbeda dengan variabel status pernikahan sehingga dalam pengembangan hipotesis memiliki arah negatif atau negatif, namun hasil yang dapat di lihat pada tabel di atas mengarah ke positif, sehingga dalam pengujian ini telah sesuai antara hipotesis dengan hasil, maka variabel usia telah lolos uji apriori.

Variabel lama pendidikan informal memiliki hipotesis negatif, dengan hasil penelitian negatif, yang artinya variabel lama pendidikan informal telah sesuai anatara hipotesis dan hasi penelitian, maka lama pendidikan informal telah lolos uji apriori.
Tabel 5 Uji Simultan

\begin{tabular}{|l|l|}
\hline Sig. & $\alpha$ \\
\hline .000 & 0,05 \\
\hline
\end{tabular}

Sumber : Olah Data

Hipotesis :

Jika nilai p-value < alpha maka menerima Ho dan menolak Ha, dan jika pvalue $>$ alpha maka menolak Ho dan menerima Ha.

Dimana :

Ho : ada pengaruh vaiabel independen terhadap variabel dependen

Ha : tidak ada pengaruh variabel independen terhadap variabel dependen

Nilai p-value Chi-square sebesar 0,000 dimana < alpha 0,05 maka menerima Ho. Sehingga secara bersama-sama variabel status pernikahan, usia dan lama pendidikan informal berpengaruh terhadap Wanita Rawan Sosial Ekonomi.

Tabel 6 Uji Signifikan

\begin{tabular}{|l|l|l|l|l|l|l|}
\hline Variabel & B & S.E. & Wald & Df & Sig. & $\operatorname{Exp}(\mathrm{B})$ \\
\hline $\begin{array}{l}\text { Status } \\
\text { Pernikahan }\end{array}$ & 3.302 & .697 & 22.4351 & .000 & 27.179 \\
\hline Usia & .026 & .039 & .439 & 1 & .507 & 1.027 \\
\hline $\begin{array}{l}\text { Lama } \\
\text { Pendidikan } \\
\text { Informal }\end{array}$ & -1.121 & .408 & 7.542 & 1 & .006 & .326 \\
\hline Constant & -1.565 & 1.811 & .747 & 1 & .388 & .209 \\
\hline
\end{tabular}

Sumber : Olah Data

Hipotesis : Jika Ho < alpha maka menerima Ho dan menolak Ha dan jika Ho > Alpha maka menolak Ho dan Menerima Ha.

Ho : ada pengaruh status pernikahan terhadap Wanita Rawan Sosial Ekonomi

Ha : tidak ada pengaruh status pernikahan terhadap Wanita Rawan Sosial Ekonomi

Dari hasil anaisis variabel status pernikahan terhadap wanita rawan sosial ekonomi nilai signifikan sebesar 0,000 dan alpha sebesar 0,05 , dengan demikian nilai 
signifikan 0,000 < 0,05 sehingga menerima Ho dan menolak $\mathrm{Ha}$, yang artimya status pernikahan ada pengaruh terhadapWRSE dengan nilai koefisien yang menunjukan angka positif, yang artinya status pernikahan signifikan berpengaruh positif terhadap wanita rawan sosial ekonomi, status pernikahan bagi seorang wanita yang mengalami pereceraian beresiko menyandang WRSE sebesar 27,179, dibandingkan dengan wanita yang masih berstatus menikah. Dengan demikian hal tersebut sesuai dengan teori yang ada, bahawasanya status pernikahan seorang wanita dengan status pernikahan baik belum menikah, menikah atau cerai serta menjadi kepala rumah tangga atau tulang punggung keluarga, dengan kesejahteraan yang rendah maka berdampak pada penyandang WRSE.

Ho : ada pengaruh usia terhadap Wanita Rawan Sosial Ekonomi

Ha : tidak ada pengaruh usia terhadap Wanita Rawan Sosial Ekonomi

Dari hasil anaisis variabel usia pernikahan terhadap wanita rawan sosial ekonomi nilai signifikan sebesar 0,507 dan alpha sebesar 0,05 , dengan demikian nilai signifikan 0,507 >0,05 sehingga menerima $\mathrm{Ha}$ dan menolak Ho, yang artinya usia tidak ada pengaruh terhadap wanita rawan sosial ekonomi, ketika usia bertambah satu tahun dengan nilai 1.023 tidak berpengaruh terhadap WRSE. Berdasarkan pada hasil penelitian adapun rata-rata usia responden tergolong pada usia produktif yaitu 15-65 tahun, pada penelitian ini usia tidak berpengaruh terhadap wanita rawan sosial ekonomi, dimana teori yang ada usia seseorang dapat mempengaruhi berbagai aktifitas, usia yang masih muda cenderung dapat melakukan aktifitas yang banyak, sedangkan usia yang sudah tua akan semakin terbatas dalam aktifitas karena terkendala pada fisiknya. Namun dalam penelitian ini tidak sesuai dengan teori tersebut, karena usia yang masih muda ataupun yang sudah tua, jika tidak bisa memenuhi kesejahteraannya maka akan menyandang WRSE, sehingga WRSE tidak memandang usia.
Ho : ada pengaruh lama pendidikan informal terhadap Wanita Rawan Sosial Ekonomi Ha : tidak ada pengaruh lama pendidikan informal terhadap Wanita Rawan Sosial Ekonomi

Dari hasil anaisis variabel lama pendidikan informal terhadap wanita rawan sosial ekonomi nilai signifikan sebesar 0,006 dan alpha sebesar 0,05 , dengan demikian nilai signifikan 0,006 < 0,05 sehingga menerima Ho dan menolak $\mathrm{Ha}$, yang artinya lama pendidikan informal ada pengaruh terhadap wanita rawan sosial ekonomi dengan nilai koefisien yang menujukan angka negatif, yang berati lama pendidikkan informal signifikan berpengaruh negatif terhadap WRSE. Ketika seorang wanita dapat menempuh lama pendidikan informal selama 1 bulan maka penyandang WRSE akan berkurang sebanyak 0,326 . Dengan demikian hal teresbut sesuai dengan teori yang ada, bahwa pendidikan informal adalah tempat untuk seseorang mendapatkan pengetahuan umum untuk mengembangkan bakat yang ada pada diri seseorang. Dalam penelitian ini hubungan antara lama pendidikan informal dengan WRSE di Kecamatan Semin sesuai dengan teori yang ada, ketika seorang wanita dapat menenpuh pendidikan secara informal demi mendapatkan pengetahuan umum sehingga dapat menggali bakat yang ada pada dirinya sehingga dapat memenuhi kesejahteranya, sehingga dapat terbebas dari penyandang WRSE.

\section{SIMPULAN}

Berdasarkan hasil penelitian dan pembahasan tentang analisis wanita rawan sosial ekonomi di Kecamatan Semin, Kabupaten Gunungkidul, dapat ditarik kesimpulan bahawa variabel status pernikahan memiliki nilai sigifikan sebesar 0,000 $<0,05$ sehingga menerima $\mathrm{Ho}$, sehingga ada pengaruh status pernikahan terhadap wanita rawan sosial ekonomi di Kecamatan Semin. Sehingga perlu adanya pembinanan atau pemberdayaan khususnya bagi penyandang WRSE dengan satus pernikahan belum menikah, menikah atau cerai, dengan 
kesejahteraan yang rendah agar dapat menjalankan kehidupan yang lebih sejahtera. variabel usia memiliki niali signifikan sebesar 0,507 >0,05 sehingga tidak ada pengaruh terhadap wanita rawan sosial ekonomi di Kecamatan Semin. lama pendidikan informal memiliki nilai signifikan sebesar 0,006 < 0,05 sehingga menerima Ho, sehingga perlu adanya sosialisasi akan pentingnya pendidikan yang ditempuh secara informal, berdasarkan hasil responden memiliki usia yang masih tergolong produktif maka diminta untuk menempuh jalur informal seperti paket A, B, C atau suatu pemeberdayaan untuk mendukung kelancaran proses pendidikan bagi penyandang wanita rawan sosial ekonomi dengan harapan mendapatkan pekerjaan yang lebih layak atau suatu keahlian baik yang dapat dikelola secra berkelompok maupun secara individu, dengan menghidupkan adanya kreatifitas bagi seorang wanita baik secara kelompok maupun secara individu maka akan memiliki kesejahteraan yang baik sehingg dapat mengurangi angka pada kasus WRSE.

\section{DAFTAR PUSTAKA}

Astuti, M. (2012). Pemberdayaan Perempuan Miskin Berbasis Pemanfaatan Sumberdaya Lokal Melalui Pendekatan Sosial Enterpreneurship (Studi Kasus di Daerah Tertinggal, Kabupaten Pasaman, Sumatera Barat), 17(03), 241-251.

Budhi, M. K. S. (2013). Analisis Faktor- faktor yang Berpengaruh terhadap Pengentasan Kemiskinan di Bali : Analisis FEM Data Panel, 1-6.

Dewi. (2012). Pastisipasi Tenaga Kerja Perempuan dalam Meningkatkan Pendapatan Keluarga. Jurnal Ekonomi Kuantitatif Terapan, 5(2), 119-124.

Juwono, H., Sultoni, A., Asumani, H., \& Wahyu, V. (2012). Pemberdayaan Wanita Rawan Sosial Ekonomi (WRSE) Melalui Penerapan Technology of Partisipatory (ToP)

Di Desa Sarimulyo Kecamata Cluring Kabupaten Banyuwangi. Sosial Dan Keagamaan, 02.

Rizal, M., \& Chandra, R. (2016). Faktorfaktor yang Mempengaruhi Wanita Berwirausaha ( Studi Kasus di Kota Langsa ), 5(2), 525534.

Sugiyono. (2012). Penelitian Kuantitatif, Kualitatif dan $R \in \mathcal{E} D$. Bandung: Alfabetha.

Supriyadi, Aris Muji Atmoko, A. I. (2018). Statistik Kesejahteraan Rakyat Kabupaten Gunungkidul 2018.pdf. In Statistik Kesjahteraan Rakyat Kabupaten Gunungkidul (p. 171).

www.bps.go.id 